\title{
HYDROCORTISONE ADMINISTERED ORALLY IN RHEUMATOID ARTHRITIS
}

\author{
EDWARD W. BOLAND
Los Angeles, California
}

(RECĖIVED FOR PUBLICATION MARCH 16, 1953)

Of the various steroid substances which have been isolated from the adrenal cortex, thus far only two, cortisone (17-hydroxy-11-dehydrocorticosterone: Kendall's Compound E) and hydrocortisone (17hydroxycorticosterone: Kendall's Compound F), have shown definite antirheumatic activity. These two hormones are closely related chemically, differing in but a single structural detail: cortisone has a ketone group, while hydrocortisone has a hydroxyl radical placed at the eleventh carbon position in the steroid nucleus (Figure). There is convincing evidence from laboratory experiments, however, to suggest that hydrocortisone may be the principal glycogenically active steroid derived from the adrenal cortex, that it probably participates more than cortisone in tissue reactions under conditions of stress (Conn and others, 1951; Jacobsen and Pincus, 1951 ; Pincus, 1949), and that its physiologic potency in animals is about twice as great as that of cortisone
(Ingle and Kuizenga, 1945; Ingle, 1946; Pabst and others, 1947). Moreover, data are rapidly accumulating from clinical investigations which indicate that hydrocortisone is, milligram for milligram, distinctly more powerful than cortisone in anti-inflammatory and anti-allergic activity, and that it may often be employed more advantageously as a therapeutic agent.

\section{Preparations of Hydrocortisone}

Two forms of hydrocortisone are available commercially: the pure hormone-hydrocortisone (free alcohol) -herein referred to as hydrocortisone; and an esterhydrocortisone acetate. The two compounds must be carefully distinguished as they differ decidedly in solubility and absorption, and in therapeutic effectiveness when given orally. Hydrocortisone is much more soluble in various media and, when administered by mouth, may be nearly twice as potent as the acetate ester in reducing the manifestations of rheumatoid arthritis

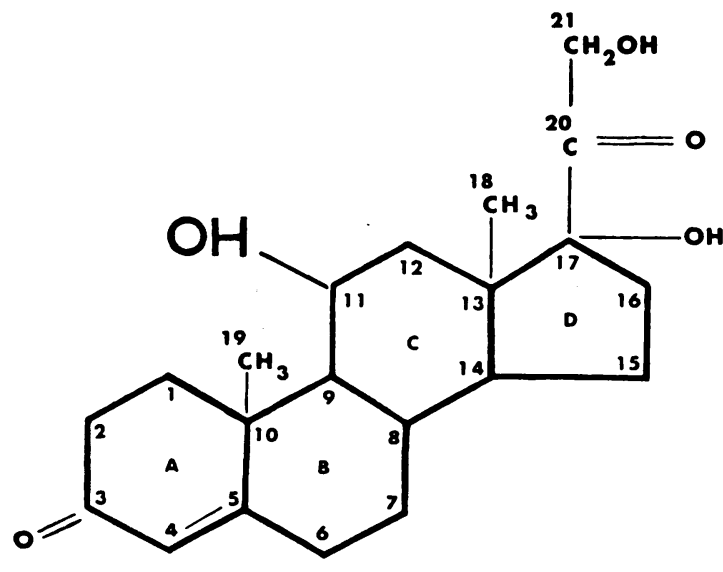

(a) HYDROCORTISONE

(17-Hydroxycorticosterone: Kendall's Compound F)

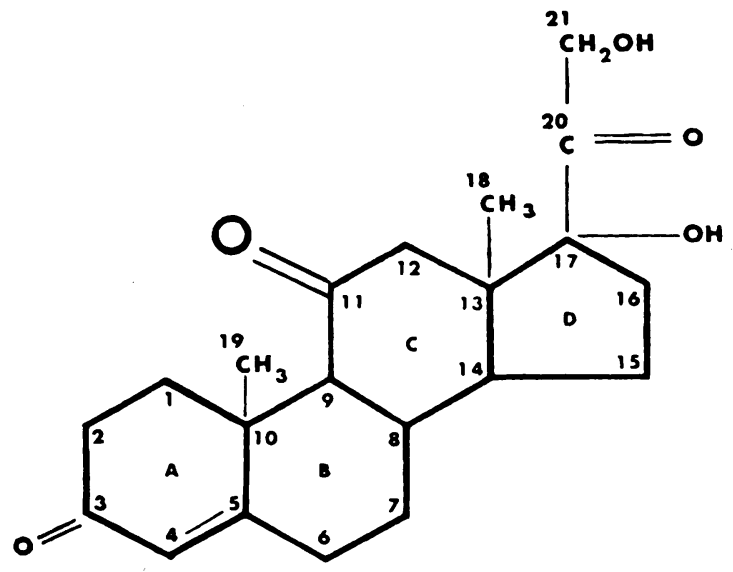

(b) CORTISONE

(17-Hydroxy-11-Dehydrocorticosterone: Kendall's Compound E)

Figure.-Chemical structure of (a) hydrocortisone and (b) cortisone. 
(Boland, 1952a). Hydrocortisone acetate is highly efficient, however, in temporarily alleviating signs of articular inflammation when injected locally into a joint.

\section{Investigations}

When long-term studies revealed that cortisone acetate failed to provide satisfactory degrees of improvement in an appreciable percentage of patients with rheumatoid arthritis, interest was aroused in finding an agent which might be used more advantageously. Better results with cortisone have been prevented mainly because objectionable endocrine complications have intruded frequently during treatment, particularly in patients with more severe disease who have required large doses of the hormone for satisfactory rheumatic control. Too often the appearance of adverse reactions has necessitated reduction of dosage to levels insufficient for adequate relief. Obviously a steroid with greater anti-inflammatory power but without a correspondingly greater tendency to produce undesired effects, br one with equal therapeutic potency and fewer liabilities, should provide superior clinical results.

In the spring of 1951 we began studies to ascertain the relative therapeutic efficiency of hydrocortisone and cortisone acetate when the substances were administered orally to patients with rheumatoid arthritis. As supplies of hydrocortisone were greatly restricted, pilot investigations were done at first to compare

(a) the maintenance doses of the hormones needed to uphold similar degrees of clinical improvement, and

(b) the response of rheumatic manifestations to initial suppressive doses of the compounds when they were administered in equivalent milligram doses.

Later, as larger quantities of material were provided, prolonged treatment studies with hydrocortisone were undertaken; these are still in progress, but have now proceeded for periods long enough to allow some provisional data.

\section{Results}

Patients transferred from Cortisone Acetate to Hydrocortisone Therapy.--In preliminary investigations, conducted by transferring the treatment of patients from one preparation directly to another, comparisons were made of the maintenance doses needed to support similar degrees of clinical improvement (Boland, 1952a, b, c). These studies disclosed that the maintenance requirements for hydrocortisone were uniformly less, and it was estimated that the hormone was at least 50 per cent. more effective, milligram for milligram, than cortisone acetate Dosage ratios of hydrocortisone to cortisone acetate ranged from $1: 1 \cdot 43$ to $1: 1 \cdot 7$, with an average of $1: 1 \cdot 59$ for the group tested. Comparisons made्द between cortisone (free alcohol) and cortisonet acetate failed to reveal any significant differences if potency. Some observations made during the stude suggested that endocrine complications from effeco tive therapeutic amounts of hydrocortisone migh? not be as frequent or as marked; signs of hormone excess displayed by several patients during cortisone acetate administration either lessened or disappeared following transfer to smaller, but equally effective doses of hydrocortisone.

Longer-term investigations have since been made $\overline{\overline{2}}$ in 44 patients transferred from cortisone acetate t $\vec{\omega}$ hydrocortisone. These patients received cortisone acetate continuously for periods ranging from 10 tô 138 weeks (average 60). Their maintenance therapy was well stabilized and the greatest degree of im provement consistent with the avoidance of seriousl $\vec{y}$ objectionable side-effects was maintained. Following transfer of treatment, the patients have, to the time of this analysis, taken hydrocortisone uninterruptedse ly for periods ranging from 12 to 66 week $\$$ (average 26).

The maintenance doses of hydrocortisone needed to uphold equal or greater degrees of clinical im provement have been materially less than for corti sone acetate in most cases; the dosage has bee lower in forty of the 44 patients (91 per cent.) approximately the same in four ( 9 per cent.), an\& greater in none. For the entire group, the dail maintenance dosage has averaged $44.5 \mathrm{mg}$. fe hydrocortisone and $62.3 \mathrm{mg}$. for cortisone acetate In spite of smaller milligram doses, better ant rheumatic control has been supported with hydro' cortisone in two-thirds of the patients. Six patients. with severe, one with moderately severe, and one with moderate disease have improved from in adequate to adequate levels since transfer.

In order to compare endocrine complications from the two steroids, many patients were purpose. selected for transfer to hydrocortisone because they exhibited signs of hormone excess during cortisone acetate administration. Among the 44 patients studied, 31 (70 per cent.) displayed adverse reaction to cortisone acetate. After transfer to hydre cortisone in smaller milligram doses, the overad incidence of adverse reactions was lowered frow 70 to 52 per cent. Of more significance, howevef, was the fact that one or more abnormal signs eithe lessened substantially or disappeared in 22 of the 31 patients (71 per cent.). Certain individua reactions tended toward correction more than others 
nervous symptoms disappeared or were reduced in thirteen of fifteen patients, oedema in nine of fifteen patients, and moon facies and supraclavicular fat pads in nine of 23 patients; but generalized obesity was corrected in only two of nine patients, and signs such as hypertrichosis (twelve patients) and irregular glycosuria (two patients) were not changed during the periods of observation.

Patients treated initially with Hydrocortisone.In a preliminary study, ten patients with rheumatoid arthritis were given hydrocortisone as initial treatment in dosages similar to those customarily employed for cortisone acetate (Boland and Headley, 1952). During these short-term investigations it was noted that the general pattern of improvement corresponded closely to that which results from cortisone acetate. With the same milligram doses, however, the onset of relief from hydrocortisone was faster and more striking, subsequent improvement progressed more quickly, and elevated erythrocyte sedimentation rates diminished more rapidly and regularly. These observations suggested that smaller doses of hydrocortisone given at the beginning of treatment might accomplish satisfactory suppression of the disease.

Subsequently, long-term studies have been instituted, using hydrocortisone as the only form of therapy. To date sixteen patients have received the hormone continuously for more than 12 weeks, some for as long as $\mathbf{3 0}$ weeks. The same general plan of treatment as that used for cortisone acetate was followed. This involved three stages:

(1) initial suppressive doses,

(2) gradual dosage reduction,

(3) maintenance therapy.

The smallest daily amount of hormone capable of controlling the disease manifestations adequately, but not necessarily completely, was considered the optimal maintenance dose for long-term therapy. Because hydrocortisone is rapidly absorbed and its effects are rapidly dissipated, the total daily dose was divided routinely into four parts, taken at mealtimes and at bedtime.

The initial suppressive doses employed for these sixteen patients were substantially less than those ordinarily prescribed for cortisone acetate in cases with corresponding degrees of disease severity. Initial daily doses of 60 to $80 \mathrm{mg}$. for severe cases, 50 to $70 \mathrm{mg}$. for moderately severe cases, and 40 to $60 \mathrm{mg}$. for moderate cases provided rapid and progressive improvement comparable to that noted with customary larger doses of cortisone acetate. With these doses euphoric reactions did not occur and nervous symptoms were uncommon; one patient experienced insomnia and "tenseness" with suppressive doses of $50 \mathrm{mg}$. daily, but these disappeared when maintenance doses of $35 \mathrm{mg}$. daily were established.

The daily amounts of hydrocortisone required to maintain satisfactory improvement in these patients were, in general, distinctly smaller than those usually uneeded with cortisone acetate; maintenance doses averaged $47 \mathrm{mg}$. for severe cases, $38 \mathrm{mg}$. for moderhately severe cases, and $30 \mathrm{mg}$. for moderate cases. Adequate improvement (marked or very marked) was maintained in fifteen of the sixteen patients, and so far only three have developed untoward signs of hormone excess, mild in each instance. These data, as well as the deductions derived from them, must, however, be considered as preliminary and tentative, as this part of the study now includes only a few patients followed for a relatively short time; and it may be anticipated that improvement may deteriorate in some patients when treatment is continued for longer periods.

\section{Summary}

Hydrocortisone (Compound F) was administered orally to two series of patients with rheumatoid arthritis. One group (44 cases) was given hydrocortisone after periods ranging from 10 to 138 weeks (average 60) during which they had received cortisone acetate (Compound E). A second group (sixteen cases) was treated with hydrocortisone from the beginning.

These clinical investigations led to the following conclusions:

(1) The antirheumatic activity of hydrocortisone is greater than that of cortisone or cortisone acetate when the substances are given orally in equivalent doses.

(2) The daily doses required for initial suppression of the disease and for maintenance of satisfactory improvement are appreciably smaller with hydrocortisone. Milligram for milligram, the antirheumatic potency of hydrocortisone may be estimated as at least 50 per cent. greater than that of cortisone or cortisone acetate, and as approximately 100 per cent. greater than that of hydrocortisone acetate.

(3) The dissociation between anti-inflammatory and certain other endocrine effects seems to be greater with hydrocortisone than with cortisone acetate, so that with smaller, but equally effective, doses of hydrocortisone, unwanted signs of hormone excess may be more easily prevented or controlled.

(4) As an agent for prolonged systemic administration in responsive chronic diseases such as rheumatoid arthritis, hydrocortisone appears to have therapeutic advantages over cortisone acetate. 


\section{REFERENCES}

Boland, E. W. (1952a) Brit, med. J., 1, 559.

(1952b). Calif. Med., 77, 1.

(1952c). J. Amer. Pharm. (Pract. Pharm. ed.), 13, 540.

-, and Headley, N. E. (1952). J. Amer. med. Ass., 148, 981.

Conn, J. W., Lawrence, L. H., and Fajans, S. S. (1951). Science, $113,713$.

Ingle, D. J. (1946). Personal communication.

-, and Kuizenga, M. H. (1945). Endocrinology, 36, 218.

Jacobsen, R. P., and Pincus, G. (1951).Amer. J. Med., 10531

Pabst, M. L., Sheppard, R., and Kuizenga, M. H. (1947). Endocrinology, 41, 55 .

Pincus, G. (1949). "Adrenal cortex function in stress; Transactions of the First Conference." Josiah Macy, Jr., Foundation, New York.

\section{Hydrocortisone par voie buccale dans l'arthrite rhumatismale \\ RÉSUMÉ}

On administra de la hydrocortisone (Composé F) par voie buccale à deux groupes de malades atteints d'arthrite rhumatismale. Un groupe (44 cas) se composait de malades antérieurement traités par l'acétate de cortisone (Composé E) pendant des périodes de 10 à 138 semaines (60 en moyenne) tandis que l'autre groupe (16 cas) n'avait pas subi ce traitement.

Ces recherches cliniques menèrent aux conclusions suivantes:

(1) L'action anti-rhumatismale de la hydrocortisone est plus forte que celle de la cortisone ou de l'acétate de cortisone, pourvu qu'on administre ces substances par voie buccale et à des doses équivalentes.

(2) Les doses quotidiennes nécessaires pour obtenir la suppression initiale de la maladie et pour maintenir une amélioration satisfaisante sont appréciablement plus faibles pour la hydrocortisone. Milligramme pour milligramme, le pouvoir antirhumatismal de la hydrocortisone peut être estimé comme étant au moins 50\% supérieur à celui de la cortisone ou de l'acétate de cortisone et à peu près $100 \%$ supérieur à celui de l'acétate de hydrocortisone.

(3) $\mathrm{La}$ dissociation entre l'effet anti-inflammatoire et les autres effets endocrines semble plus accentuée avec la hydrocortisone qu'avec l'acétate de cortisone, de manière que des doses plus faibles mais aussi efficaces de hydrocortisone sont suffisantes pour éviter ou bien controler plus facilement les manifestation néfastes de $\overline{3}$ l'excès d'hormone.

(4) En tant qu'agent thérapeutique exigeant l'administration interne prolongée dans les maladies chroniques sensibles à son action, telles que l'arthrite rhumatismale, la hydrocortisone semble l'emporter sur l'acétate de cortisone.

Hidrocortisona por vía oral en la artritis reumatoide Sumario

Se administró hidrocortisona (Compuesto F) por vía oral a dos grupos de enfermos con artritis reumatoide. $\overrightarrow{0}$ Cuarenta y cuatro enfermos previamente tratados conacetato de cortisona (Compuesto E) durante períodos de $\vec{\omega}$ 10 a 138 semanas (un promedio de 60 ) formaron uno grupo; dieciseis casos sin tratamiento hormonal previo formaron el otro.

Estas investigaciones clínicas dieron lugar a las $\overrightarrow{\mathrm{N}}$ conclusiones siguientes :

(1) La acción antirreumática de la hidrocortisona es más fuerte que la de la cortisona o del acetato de cortisona cuando se administra estas substancias por vía oral en
dosis equivalentes.

(2) Las dosis diarias de hidrocortisona necesariaspara obtener la supresión inicial de la enfermedad yc para mantener una mejoría satisfactoria son apreciablemente más pequeñas. Miligramo por miligramo, el ${ }^{\mathbb{D}}$ poder antirreumático de la hidrocortisona parece $\overrightarrow{0}$ superar al de la cortisona o del acetato de cortisonaç de un $50 \%$ al menos y al del acetato de hidrocortisona de cerca de un $100 \%$.

(3) La disociación entre el efecto anti-inflamatorio y los demás efectos endocrinos parece más acentuada conう la hidrocortisona que con el acetato de cortisona; $\overline{0}$ con dosis más pequeñas pero igualmente eficaces dễ hidrocortisona se puede evitar o controlar más facilmente la manifestaciones indeseables del exceso hormonal.

(4) Como agente precisando una administracióno interna prolongada en enfermedades crónicas que 3 responden a su acción, como en la artritis reumatoide, $\mathcal{F}$ la hidrocortisona parece terapéuticamente superior ato acetato de cortisona. 